\title{
The Implementation of Project and Research Activities in Working with Gifted Children in Terms of School-University Network Cooperation (Regional Aspect)
}

\author{
Albina R. Abdrafikova ${ }^{1}$, Rimma M. Akhmadullina ${ }^{1} \&$ Aliya A. Singatullova ${ }^{1}$ \\ ${ }^{1}$ Institute of Philology and Intercultural Communication, Kazan (Volga Region) Federal University, Kazan, \\ Russia \\ Correspondence: Albina Rinatovna Abdrafikova, Institute of Philology and Intercultural Communication, Kazan \\ (Volga Region) Federal University, Kazan, Russia. Tel: 007-917-394-5089. E-mail: albina112000@yahoo.com
}

\author{
Received: September 15, 2014 Accepted: October 27, 2014 Online Published: November 19, 2014 \\ doi:10.5539/elt.v7n12p54 URL: http://dx.doi.org/10.5539/elt.v7n12p54
}

\begin{abstract}
The article deals with regional experience in using modern strategies in teaching gifted children. The value of project and research activity is actualized as one of the most effective educational technologies in work with gifted children. The article shows examples of organization of combined project and research activities of student-teachers and pupils of specialized classes for gifted children within "school-university" framework. Such concepts as "ability", "genius" and "talent" are classified according to a single base i.e. success. As a result the nature of giftedness in its current understanding is that it is not seen as static but as a dynamic characteristic meaning a talent existing only in movement, in the development and as a consequence, its development requires certain conditions. In our study, the project-research activity of gifted children is carried out in close collaboration with the students of the department of Russian and foreign philology at Kazan (Volga region) Federal University within "school-university" framework. The special role of this form of cooperation is noted in the program and it is planned to involve the infrastructure of leading universities, innovative enterprises and creative industries to work with gifted children. A project named «Writing letters in English» has been developed to form communicative and socio-cultural skills of students.
\end{abstract}

Keywords: strategy, scientific and practical collaboration, research, educational technologies, educational surrounding

\section{Introduction}

The dynamic development of the world necessitates a modern society in an active creative personality, which in its turn actualizes the problem of early detection, training and education of gifted and talented children. Solving these problems is one of their main tasks of improving the educational system in Russia.

In recent years, gifted children have been given enormous attention at both the national and regional levels. In Tatarstan since 1999 operates a national program "Children of Tatarstan", which in 2011-2013 was called a long-term target one and contains a subroutine "Gifted children". A key objective of the subroutine was to create the search and support structures for gifted children. This problem is common with task of forming a system of work with gifted children, which is declared in the strategy of the development of education in the Republic of Tatarstan for 2010-2015 and includes: creation of an integrated system of identification, selection, development and support of gifted children; creation of a network of specialized schools and gymnasiums, which will work with gifted children using special curriculum and higher level educational programs. The purpose of the activities is the creation of a complex of social and educational conditions for self-determination and self-realization of the potential of gifted children. The special role of Kazan (Volga region) Federal University was noted in the concept of development and implementation of intellectual and creative potential of children and youth in the Republic of Tatarstan "Perspective" from 2012, where the creation of a university-based research and educational centre for gifted (talented) children and youth was planned.

\section{Literature Review}

In contemporary education dominate the individual and personal-activity approaches. According to them the main thing is the organization of activities of schoolchildren on gaining knowledge and improving skills of a 
metasubjective character with individual nature of these activities taken into consideration. For gifted students mastering of theoretical knowledge is not difficult compared to ordinary children. Therefore, the main task of an educator is the organization and management of their activities. In domestic pedagogy and psychology (S. Rubinstein, Teplov, etc.) the concept of "ability", "genius" and "talent" are classified according to a single base i.e. success. Abilities are considered as individual psychological characteristics that distinguish one person from another however, talent is viewed as a qualitatively unique combination of abilities (individual psychological characteristics) (Vinogradov, 2012).

Based on these principles, project-research activity is the most optimal solution for teaching gifted children. Experts note that gifted children are characterized by their own type of learning. It can both be revealed in high speed and ease of learning as well as learning at a slower pace, and with a subsequent rapid change in the structure of knowledge, attitudes and skills. Evidence suggests that gifted children have a high level of self-learning ability at an early age, so they need not so much focused teaching but creation of different enriched and individualized educational environment (Chichelov, 2009).

\section{Studying the Question}

Studies show that out of the total number of children $20 \%$ are gifted. Unfortunately, the talent isn't revealed in many of them. The main reasons are the common problems of gifted children with behaviour, communication and training, as well as various internal and external factors, including inadequate educational environment.

With all the variety of views on the nature of giftedness the main distinguishing feature of its current understanding is that it is not seen as static but as a dynamic characteristic meaning a talent existing only in movement, in the development and as a consequence, its development requires certain conditions. This understanding has led to the creation of concepts of giftedness, in which, along with the factors that characterize the potential of the personality the environmental factors are included. Experience in many countries shows how difficult it is to reform the educational system, change the settings in respect to gifted children, and eliminate barriers to the disclosure of their talents.

The search for adequate conditions for gifted students is realized through various forms of education: special classes and schools, centres for gifted children, individual educational programs. There is also a variety of strategies, technologies and techniques that are used in teaching gifted children. Their diversity is reduced to three main sources and variations of their use: personal experience of teachers; organized implementation of the developed or developing concepts and theories held during the experiment under supervision; spontaneous combination of methods not determined by the united conceptual logics (Fatkhullova, 2013).

Today there are certain learning strategies which may be used in different forms and methods of working with gifted children. The following strategies are worth mentioning:

1) Acceleration teaching. It is intended to change the speed of the process, rather than the composition of knowledge which a child receives ultimately. It is assumed that this method is suitable for children with a talent in foreign languages and mathematics.

2) "Jump" through the class. The use of this strategy is aimed at the student who is the most receptive to learning to be in a group of more intelligent children that will serve as an additional incentive to learning.

3) The enriching learning. The strategy of teaching gifted children based on enrichment implies acceleration of movement towards cognitive levels in the area most appropriate for the child. There are special integrated courses through which a student will not move faster but will acquire more material compared with acquiring traditional knowledge.

It is important to mention some creative and non-standard character techniques:

1) Brainstorming. There is a task to make a meaningful sentence which includes 3 present words. For example: music, literature, composer (a composer composes music based on a literary work);

2) Sinkveyn. Children are to pick up two adjectives, three verbs, four connecting words to a given word and in the end one generalized word. Words should not be repeated and the same root words can't be used either. For example: baroque - elegant, artsy, passionate, inspiring, mesmerizing, a nacreous pearl of an irregular shape, style.

3) Associative line. Students should name associative words related to some work without repeating each other. All answers are written down in a child's workbook. Children are invited to write a mini-essay based on the listed concepts. For example: Beethoven's pathetic sonata - tragic - dramatic - excited - stormy - swift - addicted - heroic - win - jubilation ... 
4) The "research training" strategy. Its essence is to activate teaching, giving a creative nature to the research and thus, giving a student the initiative in organisation of development.

Work in small groups. This is one of the most popular strategies, as it gives all students, regardless of their psychological and individual characteristics, the opportunity to participate in the work, practice their skills of cooperation, interpersonal communication (e.g. active listening for developing a common view to resolve disagreements). All this is often impossible in a big team. Working in a small group is an integral part of many interactive techniques, such as mosaic, debates, public hearings, almost all kinds of imitations, litigation etc.

Great opportunities for implementing these strategies and techniques give the use of information and communication technologies. This technology helps to access various information sources (electronic, print, instrumental, human) and instruments of teamed activities that are aimed at obtaining a specific result. Particularly relevant is the use of distance learning courses that can help to personalize the process of working with gifted children. The advantages of the distance courses, as compared to the traditional teaching method, are the following: level education; media-maintenance of the whole course; the presence of laboratory of pronunciation, writing and grammar; access to online tutors; results monitoring system to evaluate efficiency of education (Landau, 2002). Most of the authors involved in the study of gifted children note that one of the main characteristics of their cognitive demand is a cognitive motivation, which finds expression in the form of a searchable research activity aimed at finding a new one. This activity provides productive forms of thinking (Matyushkina, 2004).

As a result great potential for the implementation of various strategies in working with gifted children has a project and research activity. It provides the opportunity to include the independent research and creative problem solving (individually and in small groups) to the process of learning. The student participates as in the formulation of the problem as in the choice of methods to solve it. Thus, he is involved in the process of adaptation to the creative research work. Some authors point out that a favourable condition for the occurrence and development of giftedness is the predominance of the motive desire to succeed over the motive of avoiding failure (Shcheblanova, 2004).

In this context, the aim of our study was to organize together with the students the project-research activities of gifted students in the process of learning English and to identify its impact on the ratio of types of motivation: motivation of success and fear of failure motivation.

The special status of project research activity is reported in the new federal state educational standards for a full secondary school due to the orientation to the metasubjective content of education. Particular importance is drawn to the task of forming skills to apply knowledge in practice for Russian teens that makes them be significantly behind their peers from the most developed countries. The reason for this lag, as indicated in the State Program of the Russian Federation "Development of Education" for 2013-2020, is largely insufficient dissemination of activities (project, research) in educational technologies (Russian State Program).

In our study, the project-research activity of gifted children is carried out in close collaboration with the students of the department of Russian and foreign philology at Kazan (Volga region) Federal University within "school-university" framework. The special role of this form of cooperation is noted within the program, where in order to work with gifted children it is planned to involve the infrastructure of leading universities, innovative enterprises and creative industries.

In close scientific and practical cooperation with students within the task of preparing future employees to work with gifted children, we perform a wide variety of projects. Thus, pupils of the 10 grade carry out such projects as "The British cultural studies", "The U.S. cultural studies", etc. These projects involve intensive use of the English language sites on the Internet for cultural, cross-cultural and other language studies, moreover, students use knowledge gained from these projects in preparing for the exams. With their research work, students participate in different projects-scientific and practical conferences, competitions, contests.

The practice of using projects in teaching gifted children a foreign language showed their great interest and effectiveness in performing projects focused on getting the final product in the form of:

1) A series of quizzes on countries of the language they study (socio-cultural portrait of the country, especially etiquette behaviour in formal and informal communication, outstanding representatives of the countries acquiring languages, etc.);

2) Thematic classrooms almanacs, newspapers, and radio programs;

3) The library of essays on artistic creativity of the outstanding writers of the target language written by the students with the inclusion of the translation samples of the excerpts from different works; 
4) Illustrated thematic maps (e.g. the map of "Poetic Britain," etc.);

5) Thematic parties within foreign language interest clubs;

6) Thematic cultural board games such as "The race around Britain/the USA/Canada/Australia and New Zealand", "Visiting London", "Who is Who in the World of Science" and so on;

7) The materials of a poster type addressing to the global problems of human civilization at the present stage of development (environmental issues, war and peace, preservation of cultures and languages);

8) Bilingual materials for Russian tourists traveling abroad;

9) Mini-guides for foreigners visiting Russia, including places where students live.

With the aim of identifying gifted students being interested in project activities and enhance its effectiveness, students-teachers prepared a questionnaire in the form of a test for high school gymnasium № 19 in Kazan. Students had to choose one or more of the suggested answers.

1) Do you like the research activity?

Yes, because the research activities:

Help to develop the skills of independent learning.

Develop analytical thinking, creativity, imagination.

Develop the ability to plan the activities.

Improve search and information activities.

Develop aesthetic component: the culture of organizing the work.

Develop communication skills.

2) What difficulties do you have when writing a project?

Stage I: the choice of topic, thinking over the tasks without real purposes, unsystematic, the inability to identify the most important.

Phase II: extension, verification, specification and proof of the conjecture.

Phase III: collecting material.

Phase IV: group work.

3) What, in your opinion, is the basis for the successful implementation of the research activity?

First of all, the basis of the success is in the problem interest by the teacher.

Secondly, the dedication of the students in a task they fulfill.

4) What would you wish your peers?

To be engaged in research activities, it is so interesting, exciting, informative and useful.

Develop your knowledge and skills.

Study of the effect of design and research activities of gifted students in the ratio of types of motivation (motivation success motivation and fear of failure) was conducted by us together with the students of the Institute of Philology and Intercultural Communication Kazan (Volga Region) Federal University in the framework of a long-term project - the program "Writing letters in the English language" intended for 34 hours studying. Studies conducted on the basis of a secondary school number 19 in two 10 classes. It involved a group of 47 students aged 15-16 of both sexes, who carried out the individual and collective projects under the guidance of teachers and students. Determining the ratio of success and motivation of fear of failure using a test questionnaire MOON by A. Reana was carried out at the beginning and end of the study (Bordovskaya, 2003). The results showed that at the beginning the number of students who have scored from 1 to 7 points with the motivation of fear of failure, was 5, scored 8-13 points with uncertain motivation pole - 16 people and have scored 14-20 points with the motivation of success-26 people. At the end of the study after the program ratio has changed the number of students who have scored from 1 to 7 points with motivation fear of failure was 3 a man scored 8-13 points with uncertain motivation pole-12 people, and have scored 14-20 points with the motivation of success - 32 people (Figure1). Thus, we can say that the design and research activities may have an impact on the development of motivation to succeed, thus creating a favourable environment for the development of giftedness. 


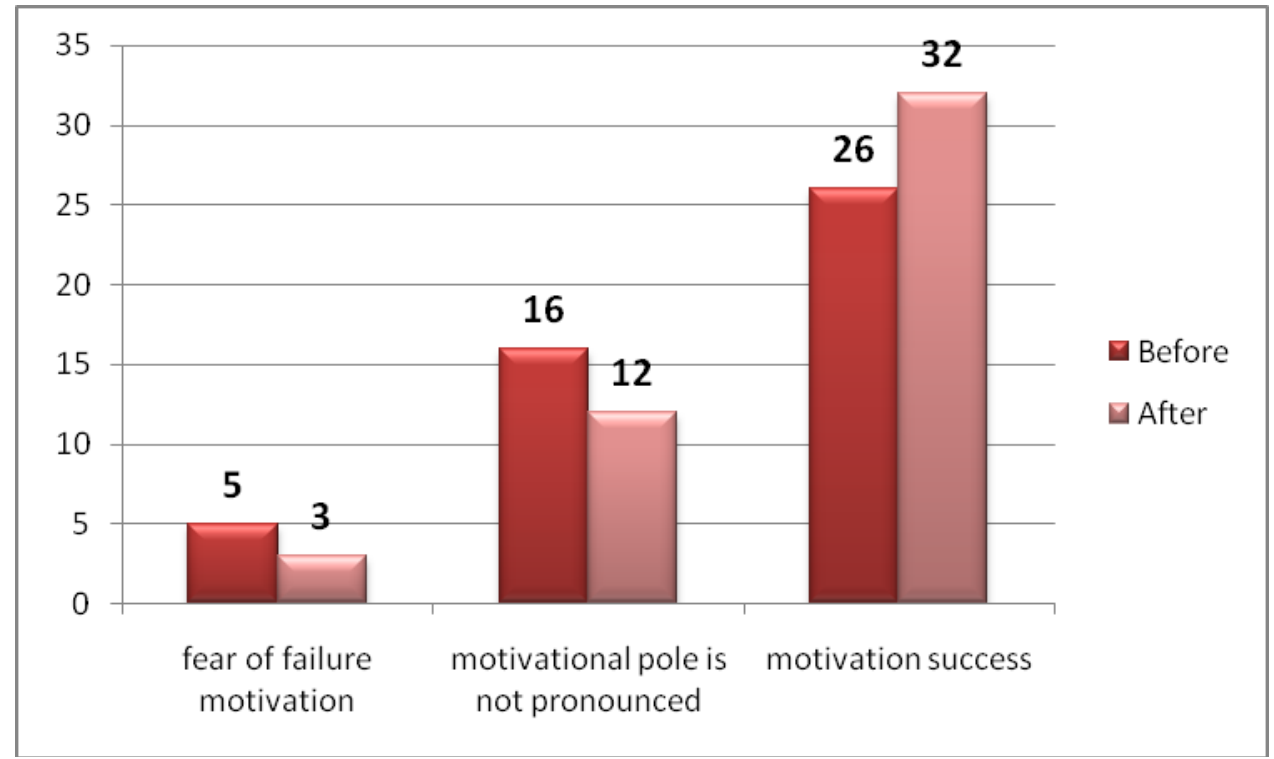

Figure 1. The comparison of relation types of motivations for success and failure avoidance at the beginning and end of the research

The content of the program was presented with the following topics. One of the long-term projects was carried out at high school № 19, the 10 "A" grade by the student-teachers from the department of the Russian and foreign philology, the institute of philology and intercultural communication at Kazan (Volga region) Federal University. The project "Writing letters in English" is intended for 34 hours. Its content is represented by the following topics:

\section{Structure and design of business letters.}

Purposes and types of business communication-8 lessons: types and register of letters; the meaning of "private letter", the term "business letter"; the purpose of a business letter and the envelope design.

$>\quad$ Structure and particular qualities of business letters-6 lessons: stylistic features of business correspondence: the letter's date, greetings, content, final lines of politeness, signature; types of abbreviations used in the design of correspondence.

Types of business letters and their features. Types of business letters- 8 lessons. Text of the letter as the main informative content: the letter of invitation, a letter of offer, a letter of inquiry, an order letter, a letter of advertising; words, combinations of specified types of business letters; samples of business correspondence.

Electronic business letters- 8 lessons. Rules of working with e-mail; features of writing e-mails; samples of electronic equity letters.

\section{Conclusions}

Thus, the practice of project research activity in "school-university" framework solves 2 tasks: first, using modern technology creates an adequate developmental learning environment contributing to the formation of motivation success and helping to identify and develop artistic and creative abilities of gifted children in a differentiated and individualized teaching; and secondly, helps to prepare students - future teachers to work with gifted students. Currently, the awareness of the need for the organization of special conditions to work with gifted children is becoming a key task of the state and society at all levels of education.

The organization of the systematic work with gifted children includes: creation of an integrated system of identification, selection, development and support of gifted children; creation of a network of specialized schools and gymnasiums, which will work with gifted children using special curriculum and individual programs.

\section{Acknowledgements}

The work is performed according to the Russian Government Program of Competitive Growth of Kazan Federal University. 


\section{References}

Bogoyavlenskaya, D. B., \& Bogoyavlenskaya, M. E. (2005). The Giftedness Psychology: Concept, types, problems. Issue 1, Moscow.

Bordovskaya, N., \& Rean, A. (2003). Pedagogy: Textbook for high schools. St. Peter.

Chichelov, I. D. (2009). About pedagogic support of a gifted child. Managing a modern school. The director of studies for the administration of schools, 8, 63-70.

Fatkhullova, K. S., Zamaletdinov, R. R., \& Yusupova, A. Sh. (2013). Information-Communicative Devices for Tatar Language Teaching. World Applied Sciences Journal, 26(1), 104. http://dx.doi.org/10.5829/idosi. wasj.2013.26.01.13466

Landau, E. (2002). Endowment requires courage: Psychological support of gifted children (A. P. Golubev, Trans.). Publishing house "Academia".

Leites, N. S. (Ed.). (1996). Psychology of gifted children and adolescents. Publishing house "Academy".

Matyushkina, A. M. (Ed.). (2004). Endowments and age. Development of creative potential of gifted children. Proc. Allowance. Moscow. Publisher Moscow Psychology-Social Institute.

Pasechnik, L. (2009). Children with special cognitive needs. Pre-school education, 1, 4-10.

Shcheblanova, E. I. (2004). Psychological diagnostics gifted students: Problems, methods, results of research and practice. Moscow. Publisher Moscow Psychology-Social Institute.

Tretyakov, N. (2011). How do we work with gifted children. Teacher, 5, 19-22.

Vinogradov, P. Y. (2012). From the experience of implementing the program "Warning: a gifted child!" Vestnik of the all-Russian olympiad, 2, 32-33.

\section{Copyrights}

Copyright for this article is retained by the author(s), with first publication rights granted to the journal.

This is an open-access article distributed under the terms and conditions of the Creative Commons Attribution license (http://creativecommons.org/licenses/by/3.0/). 